\title{
Carbon Stocks in the Small Estuarine Mangroves of Geza and Mtimbwani, Tanga, Tanzania
}

\author{
Edmond Alavaisha ${ }^{1}$ and Mwita M. Mangora ${ }^{2}$ \\ ${ }^{1}$ Institute of Resource Assessment, University of Dar es Salaam, P.O. Box 35097, Dar es Salaam, Tanzania \\ ${ }^{2}$ Institute of Marine Sciences, University of Dar es Salaam, Mizingani Road, P.O. Box 668, Zanzibar, Tanzania \\ Correspondence should be addressed to Mwita M. Mangora; mmangora@yahoo.com
}

Received 21 April 2016; Revised 2 August 2016; Accepted 29 August 2016

Academic Editor: Kurt Johnsen

Copyright (c) 2016 E. Alavaisha and M. M. Mangora. This is an open access article distributed under the Creative Commons Attribution License, which permits unrestricted use, distribution, and reproduction in any medium, provided the original work is properly cited.

\begin{abstract}
Mangrove forests offer important ecosystem services, including their high capacity for carbon sequestration and stocking. However, they face rapid degradation and loss of ecological resilience particularly at local scales due to human pressure. We conducted inventory of mangrove forests to characterise forest stand structure and estimate carbon stocks in the small estuarine mangroves of Geza and Mtimbwani in Tanga, Tanzania. Forest structure, above-ground carbon (AGC), and below-ground carbon (BGC) were characterised. Soil carbon was estimated to $1 \mathrm{~m}$ depth using loss on ignition procedure. Six common mangrove species were identified dominated by Avicennia marina (Forsk.) Vierh. and Rhizophora mucronata Lamarck. Forest stand density and basal area were 1740 stems ha ${ }^{-1}$ and $17.2 \mathrm{~m}^{2} \mathrm{ha}^{-1}$ for Geza and $2334 \mathrm{stems} \mathrm{ha}^{-1}$ and $30.3 \mathrm{~m}^{2} \mathrm{ha}^{-1}$ for Mtimbwani. Total ecosystem carbon stocks were $414.6 \mathrm{Mg} \mathrm{Cha}^{-1}$ for Geza and $684.9 \mathrm{Mg} \mathrm{Cha}^{-1}$ for Mtimbwani. Soil carbon contributed over $65 \%$ of these stocks, decreasing with depth. Mid zones of the mangrove stands had highest carbon stocks. These data demonstrate that studied mangroves are potential for carbon projects and provide the baseline for monitoring, reporting, and verification (MRV) to support the projects.
\end{abstract}

\section{Introduction}

Mangrove forests occur in fragmented stands along almost the entire coastline of Tanzania mainland. Mangroves flourish in river estuaries and deltas and in enclosed bays, lagoons, and tidal creeks. Despite representing only about $0.3 \%(108,000-115,000 \mathrm{ha})$ of the total forest area in the country $[1,2]$, these forests provide numerous ecosystem services including wood and nonwood products; buffering lands and coastal properties [1,3]; and supporting fisheries as they serve as nursery, feeding, and shelter grounds for numerous commercially important fishes and invertebrates [4-6]. In global terms, mangroves are reported to be up to five times efficient carbon sinks compared to other forms of terrestrial forests [7-9]. However, there exists large nonlinearity in ecosystem services provided by different mangrove formations $[8,10]$ that hinder generalised estimates of mangrove forest ecosystems' carbon sequestration and stocks which is complicated by local conditions such as climate and soil factors; forest age, growth, and structure; utilisation and management regime of respective forests $[3,7,11-13]$. As such, there is a considerable knowledge gap and uncertainty at local levels regarding the carbon pool size and variability of carbon sequestration within mangrove forests [14, 15]. Nonetheless, the reported high rate of mangrove carbon sequestration provides global benefits in mitigating the effects of climate change $[9,13,14]$ and demonstrates potential for livelihood enhancement through community carbon market schemes for sustainable conservation $[16,17]$.

Like in many other countries where mangroves occur, overexploitation and conversions to other land uses like solar salt pans, aquaculture, agriculture, and urban expansion are major threats to mangroves of Tanzania $[1,18]$. While the global rate of mangrove loss is approximated at $1-2 \%$ per year [19-21], there are variations at regional, national, and local scales. In Tanzania, FAO [22] estimated the rate of mangrove loss at about $0.7 \%$ per year. In most cases there are no reliable records at local scales, and where they exist, they are potentially out dated [2]. In general, mangrove degradation jeopardizes their ability to provide ecosystem goods and 


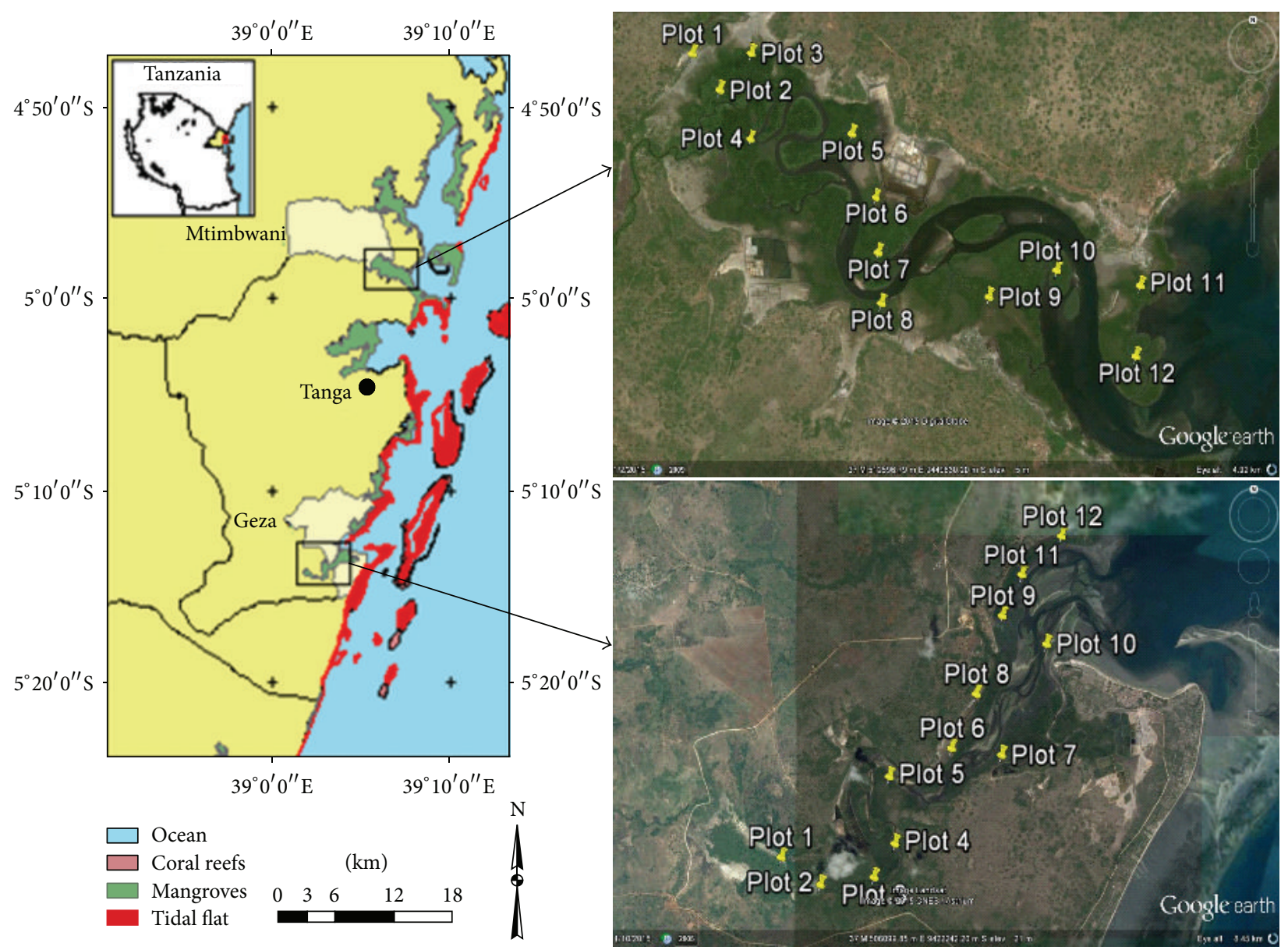

FIgURE 1: Map and Google Earth snapshots showing study sites and sampling plot locations.

services [7], but the full implication of the loss is not well understood and appreciated. This calls for urgent actions to design and implement new effective conservation strategies to protect and restore mangroves to sustain the ecosystem services that they provide $[21,23,24]$.

Over the recent past, international climate change agreements have highlighted Reduced Emissions from Deforestation and Degradation (REDD) as one of the possible costeffective strategies for mitigating the effects of climate change $[7,14,25]$. Reducing emissions aim at maintaining forest carbon stores through financial incentives for forest conservation, for example, carbon credits [26]. With the emerging market-based conservation strategies involving carbon credits in schemes like REDD+ (Reducing Emissions from Deforestation and Forest Degradation, Sustainable Management of Forests, and Enhancement of Forest Carbon Stocks in Developing Countries) and PES (Payment for Ecosystem Services), mangroves are now increasingly recognized as promising natural solutions for carbon capture and long-term storage putting them on top of the agenda in the debates on climate change adaptation mechanisms due to their high rates of carbon sequestration $[7,8,14]$. This warrants for site-specific estimations of the carbon stocks in mangrove forests. In this paper, we report on results of the inventory in the mangrove forests of Geza and Mtimbwani villages in the north-eastern region of Tanga, Tanzania, that aimed to (i) characterise the tree composition and structure; (ii) estimate the carbon stocks; and (iii) demonstrate the potential for community based carbon market schemes.

\section{Materials and Methods}

2.1. Description of Study Sites. Geza village is about $26 \mathrm{~km}$ south of the city of Tanga whereas Mtimbwani village is $16 \mathrm{~km}$ north of the city on the north coast of Tanzania (Figure 1). Mangroves of Geza are approximately 84 ha and are fed seasonally by Bongoa River while those of Mtimbwani are about 326 ha and receive freshwater discharge throughout the year from Ngole River. Common species in both forests are Avicennia marina (Forsk.) Vierh., Rhizophora mucronata Lamarck, Ceriops tagal (Perr.) C. B. Robinson, Sonneratia alba J. Smith, Bruguiera gymnorrhiza (L.) Lamarck, and Xylocarpus granatum König. The forests receive normal tidal inundation twice a day though the extent of tidal influence in upstream varies during rain and dry season. The average annual precipitation is between $1100 \mathrm{~mm}$ and $1900 \mathrm{~mm}$, relative humidity of about $76 \%$ during daytime and $96 \%$ at night, 
and the average range of atmospheric temperature is from $18^{\circ} \mathrm{C}$ to $35^{\circ} \mathrm{C}$.

2.2. Sampling Plots. Each mangrove site was divided into three zones along the river gradient from the sea landward using tidal range as criteria: lower, mid, and upper zone. In each zone, four circular nested plots of $10 \mathrm{~m}$ radius [27] spaced at approximately $200 \mathrm{~m}$ were established, giving a total of twelve sampling plots per each site (Figure 1). Plot locations were predetermined on Google Earth (GE), coordinates recorded and reached during field work by aid of the handheld GPS receiver (Garmin GPSMAP 64s).

2.3. Vegetation Inventory. Mangrove forest inventory protocols described by Kauffman and Donato [27] were adopted and modified accordingly to suite local conditions. In each plot, all trees with $<2.5 \mathrm{~cm}$ stem diameter were counted and grouped as seedlings by species. Trees with $\geq 2.5 \mathrm{~cm}$ stem diameter at breast height (DBH, $1.3 \mathrm{~m}$ above the ground) were identified by species and measured for $\mathrm{DBH}(\mathrm{cm})$ and height $(\mathrm{m})$. For the stilt rooted $R$. mucronata, DBH were measured at $30 \mathrm{~cm}$ above the highest root [28]. Standing dead wood trees were practically defined according to their death status. Trees with branches and twigs, which resemble a live tree, were categorized as "status 1," trees with large branches only as "status 2," and trees with bole (trunk) only, no branches, as "status 3." For dead and downed wood, a line-intersect method was used for counting and measuring intersections of woody pieces with diameter $>7.6 \mathrm{~cm}$ along a vertical sampling plane (transect). For the purpose of degradation, stumps were counted regardless of their species [27].

2.4. Soil Sampling for Carbon. Soil cores were retrieved from the centre of each sampling plot up to $1 \mathrm{~m}$ deep using a multistage sediment core sampler (AMS, Inc., American Falls, USA). The full length of core sampler was steadily inserted vertically into the soil at each depth stage. Soil samples were retrieved in divided segment depths of $0-30 \mathrm{~cm}, 30-$ $60 \mathrm{~cm}$, and $60-100 \mathrm{~cm}$. Each retrieved core was subdivided in $5 \mathrm{~cm}$ and mean values of each segment depth were used for analysis.

\subsection{Data Analyses}

2.5.1. Forest Structure and Composition. Forest inventory data were processed using standard analysis procedures as described by Cintron and Novelli [29] to derive forest stand characteristics: stand frequency distribution, density (stems ha $\left.\mathrm{h}^{-1}\right)$, basal area $\left(\mathrm{m}^{2} \mathrm{ha}^{-1}\right)$, relative frequency (1), relative density (2), and relative dominance (3). Ecological importance values (IV) of each species were determined by summing the respective relative frequency, relative density, and relative dominance. Importance value measures relative dominance of species by criteria of how often it occurred, number of species, and area it occupies in a community.
The species that attained the highest IV was considered the principal species:

$$
\begin{array}{r}
\text { Relative frequency }=\frac{100 F i}{\sum_{i=1}^{m} F i}, \\
\text { Relative density }=\frac{100 n i}{\sum_{i=1}^{m} n i}, \\
\text { Relative dominance }=\frac{100 B a i}{B a},
\end{array}
$$

where $n i$ is the number of trees sampled for species $i$; $m$ is the number of species; $F i$ is number of plots in which species $i$ occurred, multiplied by 100 .

2.5.2. Above- and below-Ground Biomass and Carbon Pools. Estimation of above-ground biomass (AGB) and belowground biomass (BGB) for roots in live trees used general allometric equations (4) and (5), respectively, developed by Komiyama et al. [28, 30]:

$$
\begin{aligned}
& \mathrm{AGB}=0.251 \times \rho \times(\mathrm{DBH})^{2.46}, \\
& \mathrm{BGB}=0.199 \times \rho^{0.899} \times(\mathrm{DBH})^{2.22},
\end{aligned}
$$

where $\mathrm{AGB}$ and $\mathrm{BGB}$ are biomass $(\mathrm{kg}), \mathrm{DBH}$ is diameter at breast height $(\mathrm{cm})$, and $\rho$ is average general wood density $\left(0.752 \mathrm{~g} \mathrm{~cm}^{-3}\right)$. These general equations and wood density were used because local or regional species-specific models and respective wood density for all the species have not been developed and established.

Biomass of standing dead wood was obtained by subtraction of a percentage factor from the supposed biomass of live tree derived by a general formula to account for the loss of leaf and twigs biomass. For standing dead trees of status 1 and status 2, factors of $2.5 \%$ and $10 \%$ biomass of live tree were subtracted, respectively. For status 3, standing dead trees and downed dead wood biomass were estimated by factoring average wood density $\left(0.752 \mathrm{~g} \mathrm{~cm}^{-3}\right)$ to the volume of dead wood. Volume of downed dead wood was calculated using (6) by Brown [31]:

$$
\text { Volume }\left(\mathrm{m}^{3} \mathrm{~h}^{-1}\right)=\frac{\pi^{2}\left(d_{1}^{2}+d_{2}^{2}+d_{3}^{2}+\cdots+d_{n}^{2}\right)}{8 L} .
$$

$\pi$ is constant; $d_{1}, d_{2}, \ldots, d_{n}$ are diameters of intersecting pieces of large dead wood $(\mathrm{cm})$, and $L$ is the length of the transect line for large size class $(\mathrm{m})$.

To obtain above-ground carbon (AGC) and belowground carbon (BGC) density, default values of carbon concentration were used: 0.48 for above-ground live trees, 0.5 for dead and downed trees, and 0.39 for below-ground roots as suggested by Kauffman and Donato [27] and Howard et al. [32].

2.5.3. Soil Carbon Pool. Dry combustion method was used to analyse soil carbon. Soil samples were dried at $60^{\circ} \mathrm{C}$ to constant weight for at least 72 hours and then allowed to cool to room temperature before weighing. Cooled samples 
were weighed and used for bulk density determination. Bulk density $\left(\mathrm{g} \mathrm{cm}^{-3}\right)$ was determined by dividing the oven-dry soil sample mass $(\mathrm{g})$ by the volume $\left(\mathrm{cm}^{-3}\right)$ of the sample:

$$
\begin{aligned}
& \text { Soil bulk density }\left(\mathrm{g} \mathrm{cm}^{-3}\right) \\
& \quad=\frac{\text { oven-dry sample mass }(\mathrm{g})}{\text { sample volume }\left(\mathrm{cm}^{3}\right)} .
\end{aligned}
$$

Twenty grams of oven dried subsample from each sample was ignited in a muffle furnace (AAF 11/7, Wolf Laboratories Limited, UK) at $540^{\circ} \mathrm{C}$ for 5 hours. The differences obtained between the dry weight and ignited weight (loss on ignition, LOI) indicated organic matter content expressed in percentage (\% LOI) as

$$
\begin{aligned}
& \% \text { LOI } \\
& =\left[\frac{(\text { dry mass before combustion }- \text { dry mass after combustion })}{\text { dry mass before combustion }}\right] \\
& \quad \times 100 .
\end{aligned}
$$

Soil carbon density was determined as

$$
\begin{aligned}
& \text { Soil carbon }\left(\mathrm{Mg} \mathrm{ha}^{-1}\right) \\
& =\text { bulk density }\left(\mathrm{g} \mathrm{cm}^{-3}\right) \times \text { soil depth interval }(\mathrm{cm}) \\
& \quad \times \% \text { C. }
\end{aligned}
$$

To obtain organic carbon concentration (\% C), an equation suggested by Kauffman and Donato [27] was adopted:

$$
\begin{aligned}
& \text { Organic carbon concentration }(\% \mathrm{C}) \\
& \quad=0.415 \times \% \mathrm{LOI}+2.89 .
\end{aligned}
$$

2.5.4. Total Ecosystem Carbon Stock. Estimation of ecosystem carbon density was done by summing all of the component carbon stocks of above-ground, below-ground, and soil.

2.5.5. Statistical Tests. Statistical tests were performed for descriptive and inferential statistics on forest inventory variables. Mean values were subjected to one-way Analysis of Variance (ANOVA) at significance level of 0.05 to find the differences of mean forest density, basal area, stumps, regeneration, and carbon stocks within and between sites.

\section{Results}

3.1. Forests Structure and Composition. Summary forest structural stand characteristics are presented in Table 1. Six species of mangroves were found in both sites. A. marina was the most frequently observed and dominant species in both sites. The least observed species was B. gymnorrhiza, while $S$. alba was the least dominant species. In terms of density, $R$. mucronata had high relative stem density in Geza (58.9\%) and Mtimbwani (41.8\%) whereas S. alba was the least contributing species to stem density in both Geza (0.8\%) and Mtimbwani
(1.1\%). Based on their IVs, R. mucronata was the principal species in Geza and A. marina in Mtimbwani. Seedlings and saplings count indicated $R$. mucronata and $A$. marina as the most abundant in both sites.

Mangroves of Mtimbwani had high mean stem density across the three zones compared to Geza mangroves (Figure $2(\mathrm{a})$ ). In both sites, mid zones had the highest mean stem density $\left(\right.$ Geza $=2252 \pm 810$ stems ha ${ }^{-1}$ and Mtimbwani $=$ $2944 \pm 634$ stems $^{-1}$ ) than other zones but not signifcantly different both between the sites $(p=0.075)$ and within zones ( $p=0.233$ for Geza and $p=0.115$ for Mtimbwani). For basal areas, differences were significant $(p=0.041)$ between sites where Mtimbwani site had large mean basal area than that of Geza (Figure 2(b)). The mid zones represented large basal areas in both Geza $\left(22.25 \pm 7.1 \mathrm{~m}^{2} \mathrm{ha}^{-1}\right)$ and Mtimbwani $\left(46.10 \pm 12.1 \mathrm{~m}^{2} \mathrm{ha}^{-1}\right)$ although the differences were not significant among zones in Geza $(p=0.397)$ and Mtimbwani $(p=0.114)$.

The mean number of stumps was not significantly different $(p=0.112$ ) between Geza and Mtimbwani sites (Figure 2(c)). Comparison within zones revealed a significant difference $(p=0.031)$ in mean stumps count between the zones of Geza mangroves with highest number in the upper zone $\left(49 \pm 14\right.$ stumps $\left.\mathrm{ha}^{-1}\right)$. In Mtimbwani, the difference in mean stumps count was not significant $(p=0.539)$ between the zones although the lower zone had higher count $\left(56 \pm 22\right.$ stumps ha $\left.{ }^{-1}\right)$. Fewer stumps were counted in mid zones for both sites. Overall, Geza had significantly higher mean number of seedlings than Mtimbwani $(p=0.003$; Figure 2(d)). Mean seedlings and saplings count was not significantly different between zones in both Geza $(p=$ $0.183)$ and Mtimbwani $(p=0.168)$ although counts were higher in the mid zone of Geza $(1107 \pm 437)$ and lower zone of Mtimbwani (512 \pm 91$)$.

3.2. Above- and below-Ground Carbon Stocks. The difference in AGC and BGC density was significantly different between sites ( $p=0.041$ for Geza and $p=0.046$ for Mtimbwani). There was no significant difference in AGC $(p=0.214)$ and BGC ( $p=0.158)$ between zones of Geza but the difference was significant for Mtimbwani AGC $(p=0.021)$ and BGC $(p=0.038)$ where mid zone had higher AGC and BGC compared to lower and upper zones (Figure 3). Standing live trees contributed more than $70 \%$ of the AGC (Table 2). On average, BGC in Geza and Mtimbwani represented 24.26\% and $21.93 \%$, respectively, of vegetative carbon.

\subsection{Mangrove Soil Carbon Stocks}

3.3.1. Vertical Profile of Carbon Stocks. The general profile in mean soil bulk density and carbon stock in different depths is summarized in Table 3 . The mean bulk density and soil carbon density significantly decreased with depth in both sites, Geza $(p=0.038, p=0.024)$ and Mtimbwani $(p=$ $0.007, p=0.040)$. The top $30 \mathrm{~cm}$ had higher carbon density compared to $30-60 \mathrm{~cm}$ and $60-100 \mathrm{~cm}$, demonstrating a higher $\mathrm{C} \%$ in the top layers of the soil. 


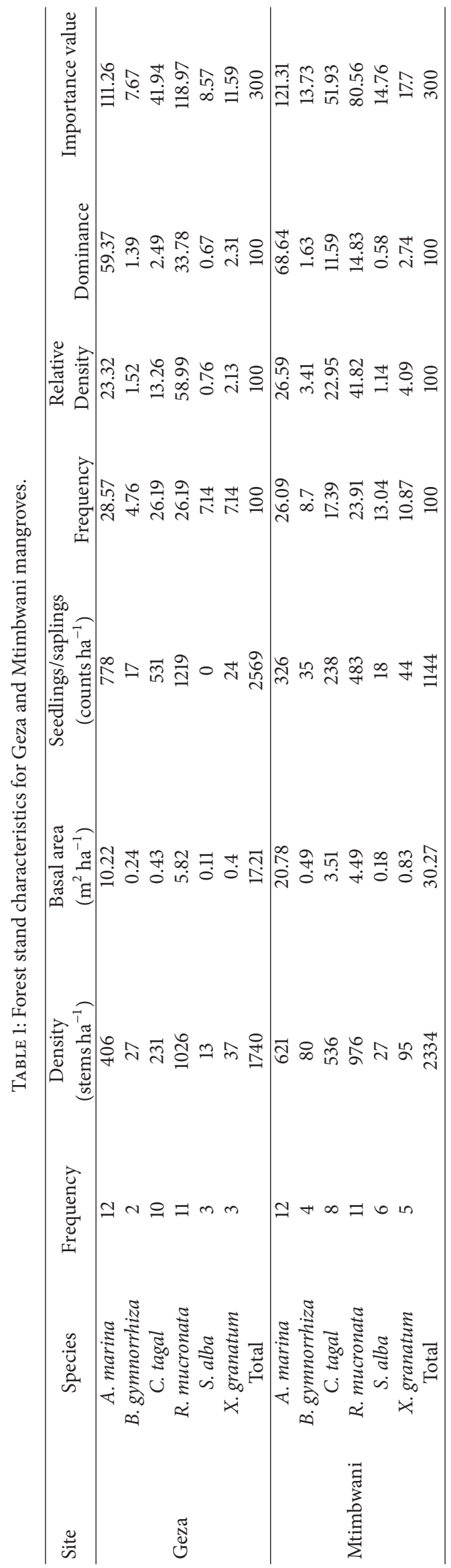




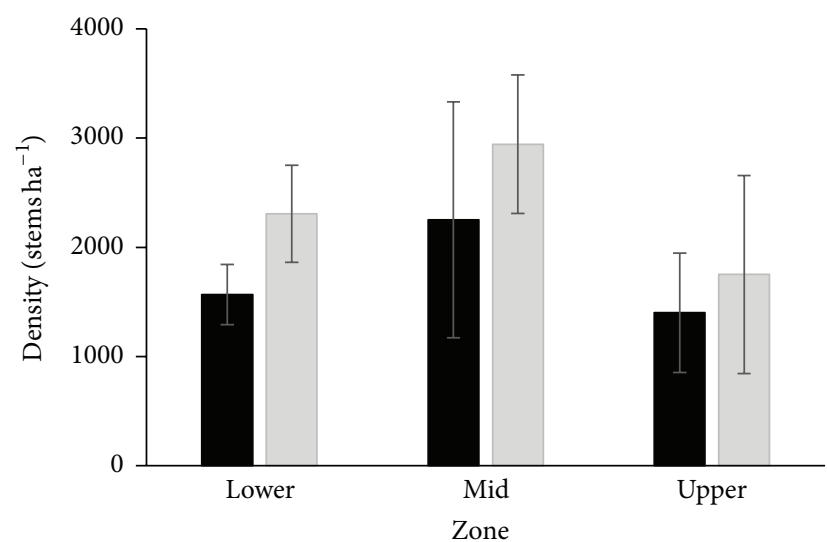

- Geza

Mtimbwani

(a)

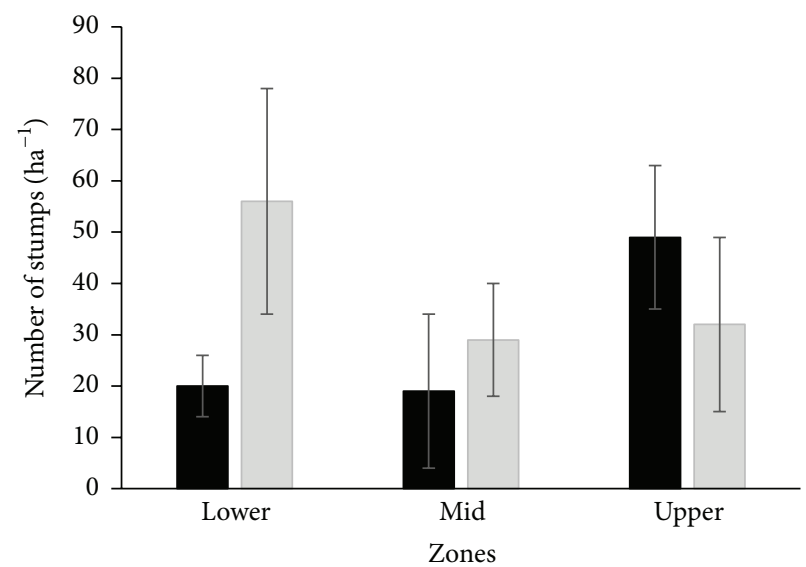

Geza

Mtimbwani

(c)

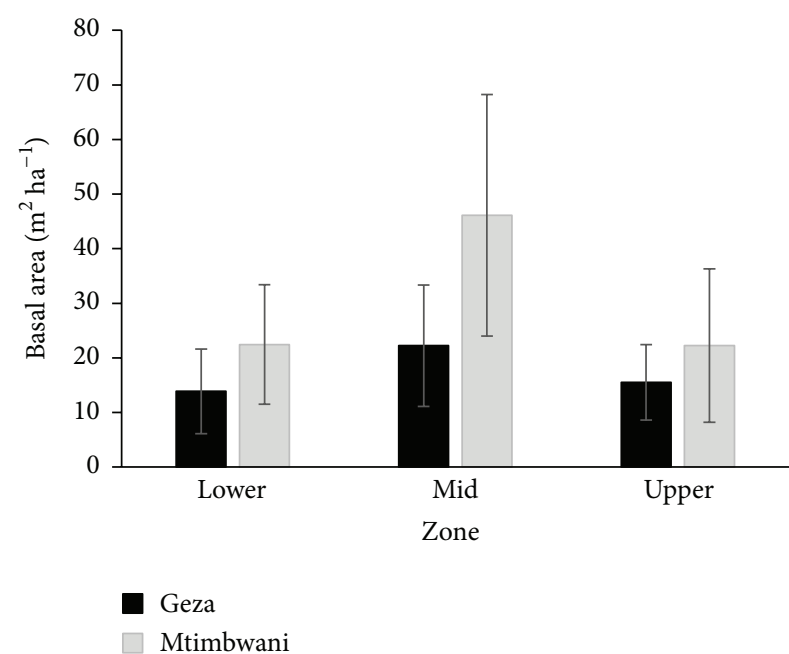

(b)

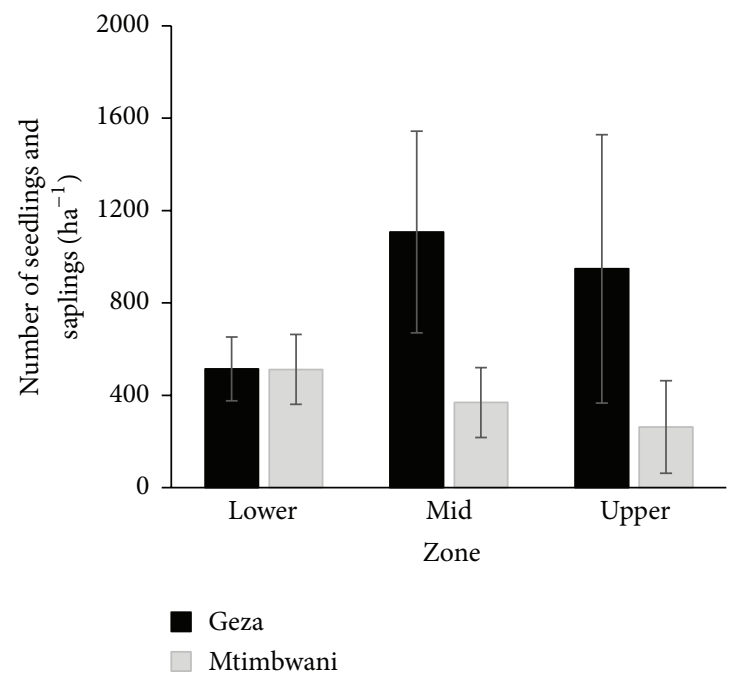

(d)

FIGURE 2: Forest structure indicating (a) stems density (b), basal area, (c) number of stumps, and (d) potential regeneration in different zones $($ mean $\pm \mathrm{SD})$.

TABLE 2: Mean AGC density $\left(\mathrm{Mg} \mathrm{C} \mathrm{ha}^{-1}\right)$ for standing live, dead and downed trees (mean $\left.\pm \mathrm{SD}\right)$.

\begin{tabular}{lcccc}
\hline Site & Component & \multicolumn{2}{c}{ Zone } \\
& & Low & Mid & $65.66 \pm 14.45$ \\
Geza & Standing live tree & $54.88 \pm 19.16$ & $102.63 \pm 30.67$ & $1.16 \pm 0.53$ \\
& Standing dead trees & $9.02 \pm 3.06$ & $0.03 \pm 0.02$ & $0.22 \pm 0.18$ \\
\hline \multirow{3}{*}{ Mtimbwani } & Downed trees & $0.23 \pm 0.08$ & $167.84 \pm 57.11$ & $99.50 \pm 45.15$ \\
& Standing live tree & $103.44 \pm 39.53$ & $133.59 \pm 126.43$ & $10.12 \pm 4.05$ \\
& Standing dead trees & $7.69 \pm 4.90$ & $0.10 \pm 0.01$ & $0.07 \pm 0.03$ \\
\hline
\end{tabular}

3.3.2. Horizontal Profile of Soil Carbon Stocks. Generally, mangroves of Mtimbwani had significantly $(p=0.002)$ higher mean soil carbon density in all zones than Geza. The variations of soil carbon density were significantly different within zones in Geza $(p=0.037)$ and Mtimbwani $(p=0.042)$. Mid zones had highest mean soil carbon density than lower and upper zones in both sites (Table 4).

3.3.3. Total Carbon Stocks. The total ecosystem carbon stock for Mtimbwani was $684.99 \mathrm{MgCha}^{-1}$ and for Geza was 


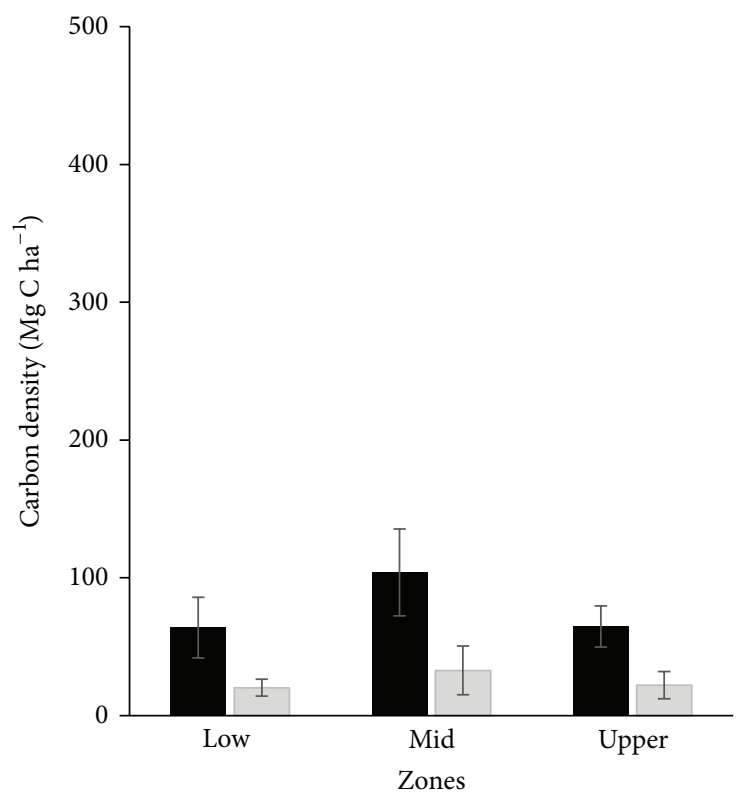

AGC

BGC

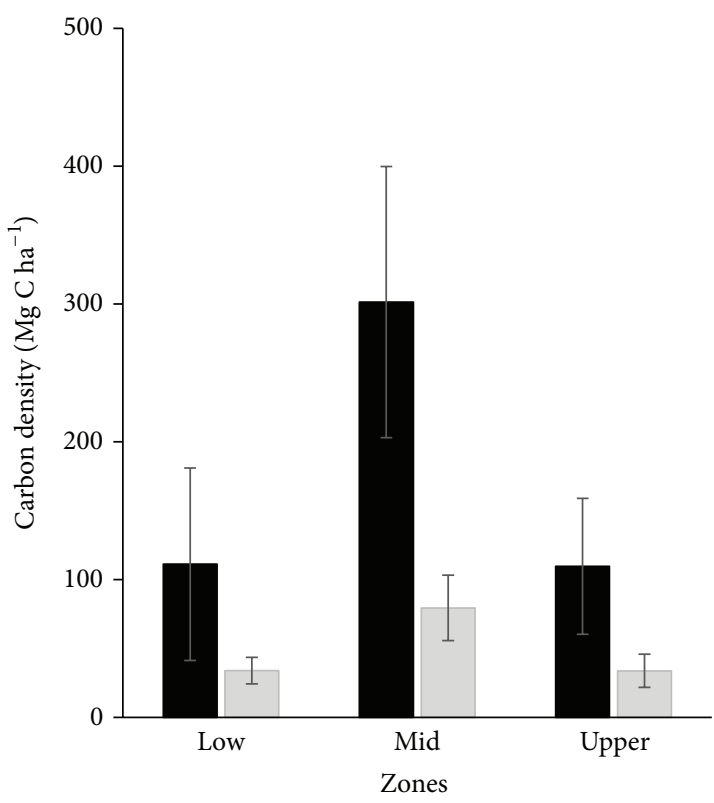

AGC

BGC

(a)

(b)

Figure 3: Mean AGC and BGC density $\left(\mathrm{MgCha}^{-1}\right)$ in different zones for (a) Geza and (b) Mtimbwani (mean \pm SD).

TABLE 3: Vertical profile of mean soil bulk density and carbon stocks (mean \pm SD).

\begin{tabular}{|c|c|c|c|}
\hline Site & Depth $(\mathrm{cm})$ & Mean soil bulk density $\left(\mathrm{g} \mathrm{cm}^{-3}\right)$ & Mean soil carbon $\left(\mathrm{MgCha}^{-1}\right)$ \\
\hline \multirow{3}{*}{ Geza } & $0-30$ & $0.62 \pm 0.20^{\mathrm{a}}$ & $106.17 \pm 7.29^{a}$ \\
\hline & $30-60$ & $0.65 \pm 0.25^{\mathrm{a}}$ & $104.80 \pm 16.14^{\mathrm{b}}$ \\
\hline & $60-100$ & $0.70 \pm 0.16^{\mathrm{b}}$ & $100.36 \pm 8.80^{c}$ \\
\hline \multirow{3}{*}{ Mtimbwani } & $0-30$ & $0.83 \pm 0.17^{\mathrm{a}}$ & $160.00 \pm 8.65^{\mathrm{a}}$ \\
\hline & $30-60$ & $0.92 \pm 0.29^{\mathrm{b}}$ & $152.59 \pm 15.42^{\mathrm{ab}}$ \\
\hline & $60-100$ & $0.94 \pm 0.12^{\mathrm{c}}$ & $149.32 \pm 5.82^{b}$ \\
\hline
\end{tabular}

Corresponding letters $\mathrm{a}, \mathrm{b}$, and $\mathrm{c}$ denote significant differences at $p<0.05$.

TABLE 4: Horizontal profile of soil carbon stocks (mean \pm SD).

\begin{tabular}{lcc}
\hline \multirow{2}{*}{ Zones } & \multicolumn{2}{c}{ Mean carbon $\left(\mathrm{Mg} \mathrm{C} \mathrm{ha}^{-1}\right)$} \\
& Geza & Mtimbwani \\
\hline Lower & $349.75 \pm 11.66^{\mathrm{a}}$ & $470.50 \pm 21.29^{\mathrm{a}}$ \\
Mid & $400.50 \pm 31.90^{\mathrm{a}}$ & $497.00 \pm 48.91^{\mathrm{b}}$ \\
Upper & $183.75 \pm 15.26^{\mathrm{b}}$ & $418.25 \pm 56.51^{\mathrm{a}}$ \\
\hline
\end{tabular}

Corresponding letters $\mathrm{a}, \mathrm{b}$, and $\mathrm{c}$ denote significant differences at $p<0.05$.

414.64 $\mathrm{Mg} \mathrm{Cha}^{-1}$ (Figure 4). Soil carbon pool was the main contributor to total carbon stock, accounting for $67.43 \%$ and $75.08 \%$ for Mtimbwani and Geza, respectively. In both sites BGC (roots) was less than $10 \%$ of the total carbon stock.

\section{Discussion}

4.1. Vegetation Structure and Composition. Six mangrove species were found in the two sites with A. marina and
R. mucronata having high relative frequency compared to other species. According to Ksawani et al. [33] the mixture of different species influences the health of forest and enhancement of carbon storage. High frequency of $A$. marina and $R$. mucronata might be attributed to their high regeneration capacity despite these species having high use preferences, particularly the latter [2]. Hamad et al. [34] reported high frequency of $A$. marina and $R$. mucronata in the mangroves of Pemba despite their high use preference for building poles and firewood. The high seedlings and saplings (2569 counts $\mathrm{ha}^{-1}$ ) implying high regeneration in Geza forest depicted the mangroves to be under human pressure such as cutting for fuelwood, building poles, and conversion for salt pans construction [2]. The higher regeneration might be contributed by opening of canopy gaps that enhances light availability to support seed germination and seedling growth $[34,35]$.

The species richness creates stable ecosystem that is more likely to self-sustain in the events of harvesting pressures [12]. 


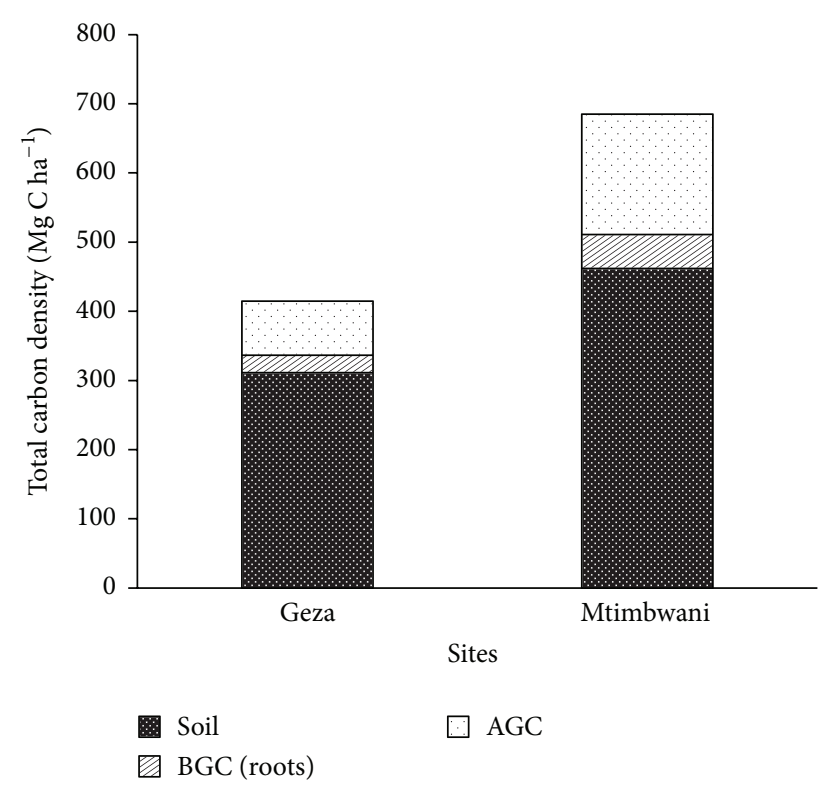

FIgURE 4: Contribution of different carbon pools to the total ecosystem carbon stocks.

Kirui et al. [36] reported that changes in species richness in Gazi Bay were likely to reduce resilience of mangrove ecosystem and make it vulnerable to natural and anthropogenic activities. Results revealed higher stem density and larger basal area in Mtimbwani compared to Geza (Figures 2(a) and 2(b)). But in general, Geza and Mtimbwani mangroves suffer similar pattern of exploitation, largely the conversion for solar salt production. The effect of human pressure is indicated by the low basal area and stem density. Although the observed stem densities and basal areas were low by standards of a healthy forest according to Bundotich et al. [37], they were high compared to reports from other areas in the region. Kairo et al. [38] reporting for Mida Creek indicated tree density to vary from 1197 to 1585 trees ha ${ }^{-1}$. Recently Trettin et al. [39] reported that overstory trees in the large Zambezi deltaic mangroves averaged to 2000 trees $\mathrm{ha}^{-1}$. Comparing the two study sites, the observed higher stem density and basal area in Mtimbwani might be attributed to the influence of freshwater from the Ngole River, unlike in Geza where Bongoa River is only seasonal. The freshwater inflow brings nutrient from upstream and creates brackish condition, which is an important aspect for mangroves growth.

Mid zones had higher stem density and basal area (Figures 2(a) and 2(b)) which may be attributed to the accessibility as it was similarly reported by Mangora and Shalli [40]. Both ends of the forests are easily accessible from land and sea, with relatively less effort required to harvest the products. Large number of stumps observed in the lower and upper zones (Figure 2(c)) demonstrates the exploitation pressures in these zones. Nonetheless, the observed higher basal areas similar to those reported by Trettin et al. [39] in the well-developed mangroves of Zambezi Delta indicate that mangroves in the study sites are still viable. Mangrove species dominance values indicated $A$. marina cover large areas in both sites, despite low stem density (Table 1). This might be attributed to the fact that most of $A$. marina species were large in size, an indication that the species is less preferred for cutting as compared to the species of the family Rhizophoraceae and therefore has opportunities to grow into large trees. Similar explanation was given for $R$. mucronata of Mida Creek [38] and Ngomeni forest [37], where $R$. mucronata was not a dominant species but had high stem density. Importance values indicated $A$. marina and $R$. mucronata as the most common species in both sites, suggesting their potential for restoration to maximise carbon stocks and sustain wood stocks.

4.2. Above- and below-Ground (Roots) Carbon Pools. Standing live trees were the major contributor to AGC followed by standing dead trees and downed trees (Table 2). The present reported AGC for Geza and Mtimbwani were comparable to those reported by Kirui et al. [41] and Cohen et al. [42] for Gazi Bay and Vanga which are a little further north of the study sites across the border in Kenya, where carbon density estimate was between 125 and $226 \mathrm{MgCha}^{-1}$, and to those recently reported by Trettin et al. [39] for the large deltaic mangroves of Zambezi in Mozambique which ranged from 111 to $483 \mathrm{Mg} \mathrm{ha}^{-1}$ but exceeded those reported by Cohen et al. [42] for Mtwapa Creek (36.4 $\mathrm{Mg} \mathrm{Cha}^{-1}$ ) and Mida Creek (38.5 $\mathrm{Mg} \mathrm{Cha}^{-1}$ ) in Kenya and Sitoe et al. [43] for Sofala Bay (33.3 $\mathrm{MgC} \mathrm{ha}^{-1}$ ) in Mozambique. The possible explanation for the variation may be the structural characteristics of the forests [33], whereby mangroves of Mtimbwani and Geza had comparably large basal area and high stem density, which also suggest the low level of degradation. The BGC (roots) was the least pool of carbon after soil and AGC components (Figure 4). Nonetheless, the obtained mean estimates of BGC density were above those reported by Sitoe et al. [43] and Fatoyinbo et al. [44] in Mozambique. These differences in the amount of carbon stored in roots between sites and zones might be explained by differences in nutrient cycling, sediment characteristics, and related growth rates $[9,45]$.

4.3. Soil Carbon Pools. Soil bulk density increased while mean soil carbon decreased with depth (Table 3). Similar trends were reported by Lupembe [46] in the Rufiji Delta (Tanzania), Rahman et al. [47] in the Sundarbans (Bangladesh), Sitoe et al. [43] in Sofala Bay (Mozambique), and Stringer et al. [13] in the Zambezi Delta (Mozambique). Increasing bulk density is associated with the increase of soil compactness as depth increases and decrease in concentration of organic matter $[13,32]$ which also explains high carbon in upper soil layer as concentration of organic matter triggered by biological activity, particularly litter deposition and decomposition on the soil surface, is high [7, 45].

The average soil carbon density estimated for up to $1 \mathrm{~m}$ deep was $311.3 \pm 87.2 \mathrm{MgCha}^{-1}$ for Geza and $461.9 \pm$ 88.1 $\mathrm{MgCha}^{-1}$ for Mtimbwani. The estimated soil carbon was comparable to that reported from Madagascar by Jones et al. [16] who found $446.2 \mathrm{MgC} \mathrm{ha}^{-1}$. The present values of soil carbon density were higher than those reported by Sitoe 
et al. [43] who found an average of $218.5 \mathrm{Mg} \mathrm{Cha}^{-1}$ in Sofala Bay (Mozambique) but low compared to estimates reported by Kauffman et al. [48] for the Mangroves of Yap Micronesia (724.8 $\mathrm{MgCha}^{-1}$ ) and Donato et al. [7] for the coastal fringe mangroves of Republic of Palau (527.7 $\mathrm{MgC} \mathrm{ha}^{-1}$ ). Again, site-specific difference in forest structure, composition, history of exploitation, and management regimes may explain the variations and warrant site-specific conservation prescriptions.

4.4. Total Ecosystem Carbon Stocks. Total ecosystem carbon stocks were different between sites whereby Geza had 414.6 $\mathrm{Mg} \mathrm{C} \mathrm{ha}^{-1}$ and Mtimbwani had 684.9 $\mathrm{Mg} \mathrm{Cha}^{-1}$. These values were within the range of ecosystem carbon stocks reported from other sites in the region $[13,16,17,42,43]$ and those reported from other regions $[32,49]$, which ranges from 55 to $800 \mathrm{MgC} \mathrm{ha}^{-1}$. Higher ecosystem carbon stocks have been reported from the Indo-West Pacific with values ranging from 830 to $1131 \mathrm{MgCha}^{-1}[7,48]$. In terms of the pattern of carbon density with tidal gradient, mid zones had large stocks. This may be attributed to forest density and basal area, similar to the observation by Stringer et al. [13] in the Zambezi Delta. The observed low density of stumps in the mid zones, implying low deforestation, further supports this. Other reports suggest that differences in mangrove carbon stocks between sites and zones may as well be due to differences in forest age, forest conservation and management status, soil depth, and soil water content [13, 16, 27], factors which need further research for the study sites. The influence of these local factors demonstrates that estimation of carbon stocks in mangroves cannot be generalised, especially for MRV and their potential in climate change mitigation and adaptation.

Despite the differences in mangrove carbon stocks for different ecosystems across the world, the relative contribution of various ecosystem components shows a similar trend. Above-ground carbon density contributed $18.87 \%$ and $25.41 \%$ of total ecosystem carbon estimates in Geza and Mtimbwani, respectively. Kauffman et al. [48] reported that AGC accounts for about 18 to $25 \%$ of total ecosystem carbon. Observations on BGC density were also coherent with values reported from other places, which range from 6 to 23\% [7]. Similar to reports from other assessments [7, 13, 43, 48], the soil carbon pool was dominant representing $75.08 \%$ and $67.43 \%$ of total ecosystem carbon stock for Geza and Mtimbwani mangroves, respectively. Soil carbon values of the present study and those from other areas demonstrate the role of mangrove soil as an important carbon sink. This carbon pool has a significant contribution to primary productivity and health of the forests [9] that can ensure mangroves are able to sustain in providing other ecosystem services that are valuable to local communities.

4.5. Potential for Carbon Markets. Detailed analysis of the socioeconomic factors is not presented here but indicated that communities in Geza and Mtimbwani are substantially dependent on ecosystem services provided by mangroves. Similar to other reports [40], low income and low level of environmental education contributed to rapid degradation of mangrove forests and eventually structure and carbon stocks. Most households in Geza and Mtimbwani are engaged in harvesting and selling of mangrove products to maximise their income in addition to household consumption [50]. Mangroves are widely used as cheap construction materials to build and maintain their homes and a source of household fuelwood. Mangrove areas are also converted to solar salt pans. The observed large amount of carbon stored in the two mangrove communities is vulnerable to loss from such human pressures that are often coupled with the natural phenomena such as sea level rise, disrupted water budgets, and increased salinity. Bhomia et al. [14] suggested that carbon stocks $>500 \mathrm{Mg} \mathrm{Cha}^{-1}$ confirm the potential of mangroves as sinks and that any loss in such mangrove forests exposes them to significant carbon sources. These data sets provide a clear message that concerted efforts in conservation and management of mangrove areas are warranted to minimize the emissions. The quantification of fairly large carbon stocks in the mangroves of Mtimbwani and Geza provides key baselines for informed policy and planning decisions to safeguard mangroves and restore degraded areas.

Opportunities exist because of the growing realization of the impacts of mangrove degradation coupled with those of climate change that shape the community willingness for conservation initiatives to address mangrove degradation. Emerging market-based conservation through carbon projects (carbon credits) is a potential opportunity to incentivize Geza and Mtimbwani communities, providing them with necessary resources needed to sustain conservation and the carbon sink function of mangroves. This is further supported by the observed vegetative structural indices that proved that mangroves of Geza and Mtimbwani are still viable for self-sustenance given appropriate conservation measures. Incentivized communities would conduct selfenforcement in restoring and protecting the mangroves as they would devise alternative sources of wood products for local consumption through tree planting of fast growing terrestrial based species.

\section{Conclusion}

This study presented findings that demonstrate that forest structure and ecosystem carbon densities are key elements to voluntary carbon market schemes. Inventory of both mangrove vegetation and soil carbon demonstrated comparatively higher carbon stocks in the study sites and therefore reflecting their potential for carbon markets. Geza and Mtimbwani communities have experience in collaborative arrangements in mangroves management from the former Tanga Coastal Zone Conservation and Development programme [51]. The estimated carbon stocks have provided baseline data for future MRV that is important in supporting carbon projects. Based on present findings and the potential for carbon projects, it is recommended that (a) permanent plots should be established for MRV of additionality in terms of health and carbon stocks; (b) vulnerability assessment and monitoring should be done to assess mangrove cover changes over 
time and predict extents of human impacts on mangroves; (c) collaborative management should be strengthened by harmonising rules and regulations across stakeholders; (d) detailed studies should be done to investigate whether existing governance mechanism can favour initiation of carbon market schemes.

\section{Competing Interests}

The authors declare that there are no competing interests regarding the publication of this paper.

\section{Acknowledgments}

This work was funded by a research grant from the Bilateral Marine Science Programme supported by Sida through the Institute of Marine Sciences of the University of Dar es Salaam. The authors appreciate the assistance offered during field work by Mr. M. Yasini, Mr. A. Kurungu, Mr. A. Nyangusi, and Mr. A. Mabwela and the laboratory work by Mr. M. Mwadini.

\section{References}

[1] A. K. Semesi, "Developing management plans for the mangrove forest reserves of mainland Tanzania," Hydrobiologia, vol. 247, no. 1-3, pp. 1-10, 1992.

[2] Y. Wang, G. Bonynge, J. Nugranad et al., "Remote sensing of Mangrove change along the Tanzania coast," Marine Geodesy, vol. 26, no. 1-2, pp. 35-48, 2003.

[3] A. K. Semesi, Y. D. Mgaya, M. H. S. Muruke, J. Francis, M. Mtolera, and G. Msumi, "Coastal resources utilization and conservation issues in Bagamoyo, Tanzania," Ambio, vol. 27, no. 8, pp. 635-644, 1998.

[4] B. R. Lugendo, I. Nagelkerken, G. Kruitwagen, G. Van Der Velde, and Y. D. Mgaya, "Relative importance of mangroves as feeding habitats for fishes: a comparison between mangrove habitats with different settings," Bulletin of Marine Science, vol. 80, no. 3, pp. 497-512, 2007.

[5] G. Kruitwagen, I. Nagelkerken, B. R. Lugendo, Y. D. Mgaya, and S. E. W. Bonga, "Importance of different carbon sources for macroinvertebrates and fishes of an interlinked mangrovemudflat ecosystem (Tanzania)," Estuarine, Coastal and Shelf Science, vol. 88, no. 4, pp. 464-472, 2010.

[6] I. A. Kimirei, M. M. Igulu, M. Semba, and B. R. Lugendo, "Small estuarine and non-estuarine mangrove ecosystems of Tanzania: overlooked coastal habitats?" in Estuaries: A Lifeline of Ecosystem Services in the Western Indian Ocean, S. Diop, P. Scheren, and J. F. Machiwa, Eds., Estuaries of the World, pp. 209-226, Springer, Cham, Switzerland, 2016.

[7] D. C. Donato, J. B. Kauffman, D. Murdiyarso, S. Kurnianto, and M. Stidham, "Mangroves among the most carbon-rich tropical forests and key in land use carbon emissions," Nature Geosciences, vol. 4, pp. 293-297, 2011.

[8] D. M. Alongi, "Carbon payments for mangrove conservation: ecosystem constraints and uncertainties of sequestration potential," Environmental Science and Policy, vol. 14, no. 4, pp. 462470, 2011.

[9] D. M. Alongi, "Carbon cycling and storage in mangrove forests," Annual Review of Marine Science, vol. 6, pp. 195-219, 2014.
[10] K. C. Ewel, R. R. Twilley, and J. E. Ong, "Different kinds of mangrove forests provide different goods and services," Global Ecology and Biogeography Letters, vol. 7, no. 1, pp. 83-94, 1998.

[11] P. A. W. Abuodha and J. G. Kairo, "Human-induced stresses on mangrove swamps along the Kenyan coast," Hydrobiologia, vol. 458, pp. 255-265, 2001.

[12] J. A. Okello, N. Schmitz, J. G. Kairo, H. Beeckman, F. DahdouhGuebas, and N. Koedam, "Self-sustenance potential of periurban mangroves: a case of Mtwapa creek Kenya," Journal of Environmental Science and Water Resources, vol. 2, no. 8, pp. 277-289, 2013.

[13] C. E. Stringer, C. C. Trettin, S. J. Zarnoch, and W. Tang, "Carbon stocks of mangroves within the Zambezi River Delta, Mozambique," Forest Ecology and Management, vol. 354, pp. 139-148, 2015.

[14] R. K. Bhomia, J. B. Kauffman, and T. N. McFadden, "Ecosystem carbon stocks of mangrove forests along the Pacific and Caribbean coasts of Honduras," Wetlands Ecology and Management, vol. 24, no. 2, pp. 187-201, 2016.

[15] M. M. Mangora, M. S. Shalli, I. S. Semesi et al., "Designing a mangrove research and demonstration forest in the rufiji delta, Tanzania," in Proceedings of the 5th Interagency Conference on Research in the Watersheds, C. E. Stringer, K. W. Krauss, and J. S. Latimer, Eds., pp. 190-192, U.S. Department of Agriculture Forest Service, Southern Research Station, Asheville, NC, USA.

[16] T. G. Jones, H. R. Ratsimba, L. Ravaoarinorotsihoarana, G. Cripps, and A. Bey, "Ecological segregation of the late jurassic stegosaurian and iguanodontian dinosaurs of the morrison formation in north america: pronounced or subtle?" Forests, vol. 5, no. 1, pp. 177-205, 2014.

[17] T. Jones, H. Ratsimba, L. Ravaoarinorotsihoarana et al., "The dynamics, ecological variability and estimated carbon stocks of mangroves in Mahajamba Bay, Madagascar," Journal of Marine Science and Engineering, vol. 3, no. 3, pp. 793-820, 2015.

[18] B. Lugendo, "Mangroves, salt marshes and seagrass beds", in The Regional State of the Coast Report: Western Indian Ocean, UNEP-Nairobi Convention and WIOMSA, Eds., pp. 53-68, UNEP and WIOMSA, Nairobi, Kenya, 2015.

[19] I. Valiela, J. L. Bowen, and J. K. York, "Mangrove forests: one of the world's threatened major tropical environments," BioScience, vol. 51, no. 10, pp. 807-815, 2001.

[20] D. M. Alongi, "Present state and future of the world's mangrove forests," Environmental Conservation, vol. 29, no. 3, pp. 331-349, 2002.

[21] N. C. Duke, J.-O. Meynecke, S. Dittmann et al., "A world without mangroves?” Science, vol. 317, no. 5834, pp. 41-42, 2007.

[22] FAO, The World's Mangroves 1980-2005. A Thematic Study Prepared in the Framework of the Global Forest Resources Assessment 2005, FAO, Rome, Italy, 2007.

[23] P. E. R. Dale, J. M. Knight, and P. G. Dwyer, "Mangrove rehabilitation: a review focusing on ecological and institutional issues," Wetlands Ecology and Management, vol. 22, no. 6, pp. 587-604, 2014.

[24] UNEP, The Importance of Mangroves to People: A Call to Action, Edited by J. Van Bochove, E. Sullivan and T. Nakamura, United Nations Environment Programme World Conservation Monitoring Centre, Cambridge, UK, 2014.

[25] IPCC, Climate Change 2014: Synthesis Report. Contribution of Working Groups I, II and III to the Fifth Assessment Report of the Intergovernmental Panel on Climate Change, IPCC, Geneva, Switzerland, 2014. 
[26] J. G. Kairo, C. Wanjiru, and J. Ochiewo, "Net pay: economic analysis of a replanted mangrove plantation in Kenya," Journal of Sustainable Forestry, vol. 28, no. 3-5, pp. 395-414, 2009.

[27] J. B. Kauffman and D. C. Donato, "Protocols for the measurement, monitoring and reporting of structure, biomass and carbon stocks in mangrove forests," Working Paper 86, CIFOR, Bogor, Indonesia, 2012.

[28] A. Komiyama, S. Poungparn, and S. Kato, "Common allometric equations for estimating the tree weight of mangroves," Journal of Tropical Ecology, vol. 21, no. 4, pp. 471-477, 2005.

[29] G. Cintron and Y. S. Novelli, "Methods for studying mangrove structure," in The Mangrove Ecosystem: Research Methods, S. C. Snedaker and J. G. Snedaker, Eds., pp. 91-113, UNESCO, Paris, France, 1984.

[30] A. Komiyama, J. E. Ong, and S. Poungparn, "Allometry, biomass, and productivity of mangrove forests: a review," Aquatic Botany, vol. 89, no. 2, pp. 128-137, 2008.

[31] J. K. Brown, "A planar intersects method for sampling fuel volume and surface area," Forest Science, vol. 17, pp. 96-102, 1971.

[32] J. Howard, S. Hoyt, K. Isensee, E. Pidgeon, and M. Telszewski, Eds., Coastal Blue Carbon: Methods for Assessing Carbon Stocks and Emissions Factors in Mangroves, Tidal Salt Marshes, and Seagrass Meadows, Conservation International, Intergovernmental Oceanographic Commission of UNESCO, International Union for Conservation of Nature, Arlington, Va, USA, 2014.

[33] I. Ksawani, J. Kmarusaman, and M. I. Nurum-Nadhirah, "Biological diversity assessment of Tok Bali mangrove forest, Kelantan, Malaysia," WSEAS Transactions on Environment and Development, vol. 3, no. 2, pp. 37-44, 2007.

[34] H. M. Hamad, I. S. Mchenga, and M. I. Hamisi, "Status of exploitation and regeneration of mangrove forests in Pemba Island, Tanzania," Global Journal of Bio-Science and Biotechnology, vol. 3, no. 1, pp. 12-18, 2014.

[35] K. Kathiresan and B. L. Bingham, "Biology of mangroves and mangrove ecosystems," Advances in Marine Biology, vol. 40, pp. 81-251, 2001.

[36] B. Y. K. Kirui, J. G. Kairo, M. W. Skov, M. Mencuccini, and M. Huxham, "Effects of species richness, identity and environmental variables on growth in planted mangroves in Kenya," Marine Ecology Progress Series, vol. 465, pp. 1-10, 2012.

[37] G. Bundotich, M. Karachi, E. Fondo, and J. G. Kairo, "Structural inventory of mangrove forests in Ngomeni," in Advances in Coastal Ecology: People, Processes and Ecosystems in Kenya, J. Hoorweg and N. Muthiga, Eds., pp. 111-121, African Studies Centre, Leiden, Netherlands, 2009.

[38] J. G. Kairo, F. Dahdouh-Guebas, P. O. Gwada, C. Ochieng, and N. Koedam, "Regeneration status of mangrove forests in Mida Creek, Kenya: a compromised or secured future?” Ambio, vol. 31, no. 7-8, pp. 562-568, 2002.

[39] C. C. Trettin, C. E. Stringer, and S. J. Zarnoch, "Composition, biomass and structure of mangroves within the Zambezi River Delta," Wetlands Ecology and Management, vol. 24, no. 2, pp. 173-186, 2016.

[40] M. M. Mangora and M. S. Shalli, "Socio-economic profiles of communities adjacent to Tanga Marine Reserve Systems, Tanzania: key ingredients to general management planning," Current Research Journal of Social Sciences, vol. 4, no. 2, pp. 141149, 2012.

[41] B. Kirui, J. G. Kairo, and M. Karachi, "Allometric equations for estimating above ground biomass of Rhizophora mucronata
Lamk. (Rhizophoraceae) mangroves at Gaxi Bay, Kenya," Western Indian Ocean Journal of Marine Science, vol. 5, no. 1, pp. 2734, 2006.

[42] R. Cohen, J. Kaino, J. A. Okello et al., "Propagating uncertainty to estimates of above-ground biomass for Kenyan mangroves: a scaling procedure from tree to landscape level," Forest Ecology and Management, vol. 310, pp. 968-982, 2013.

[43] A. A. Sitoe, L. J. C. Mandlate, and B. S. Guedes, "Biomass and carbon stocks of Sofala bay mangrove forests," Forests, vol. 5, no. 8, pp. 1967-1981, 2014.

[44] T. E. Fatoyinbo, M. Simard, R. A. Washington-Allen, and H. H. Shugart, "Landscape-scale extent, height, biomass, and carbon estimation of Mozambique's mangrove forests with Landsat ETM+ and Shuttle Radar Topography Mission elevation data," Journal of Geophysical Research, vol. 113, pp. 1-13, 2008.

[45] P. Mfilinge, N. Atta, and M. Tsuchiya, "Nutrient dynamics and leaf litter decomposition in a subtropical mangrove forest at Oura Bay, Okinawa, Japan," Trees, vol. 16, no. 2-3, pp. 172-180, 2002.

[46] I. B. Lupembe, Carbon stocks in the mangrove ecosystem of rufiji river delta, Rufiji District, Tanzania [M.S. thesis], Sokoine University of Agriculture, Morogoro, Tanzania, 2014.

[47] M. M. Rahman, M. Nabiul Islam Khan, A. K. Fazlul Hoque, and I. Ahmed, "Carbon stock in the Sundarbans mangrove forest: spatial variations in vegetation types and salinity zones," Wetlands Ecology and Management, vol. 23, no. 2, pp. 269-283, 2015.

[48] J. B. Kauffman, C. Heider, T. G. Cole, K. A. Dwire, and D. C. Donato, "Ecosystem carbon stocks of Micronesian mangrove forests," Wetlands, vol. 31, no. 2, pp. 343-352, 2011.

[49] G. Wang, D. Guan, M. R. Peart, Y. Chen, and Y. Peng, "Ecosystem carbon stocks of mangrove forest in Yingluo Bay, Guangdong Province of South China," Forest Ecology and Management, vol. 310, pp. 539-546, 2013.

[50] B. A. Tarimo, Analysis of local governance in conservation of mangrove forests of Geza and Mtimbwani Coastal Communities [M.S. thesis], University of Dar es Salaam, Dar es Salaam, Tanzania, 2015.

[51] S. Wells, M. Samoilys, S. Makoloweka, and H. Kalombo, "Lessons learnt from a collaborative management programme in coastal Tanzania," Ocean and Coastal Management, vol. 53, no. 4, pp. 161-168, 2010. 

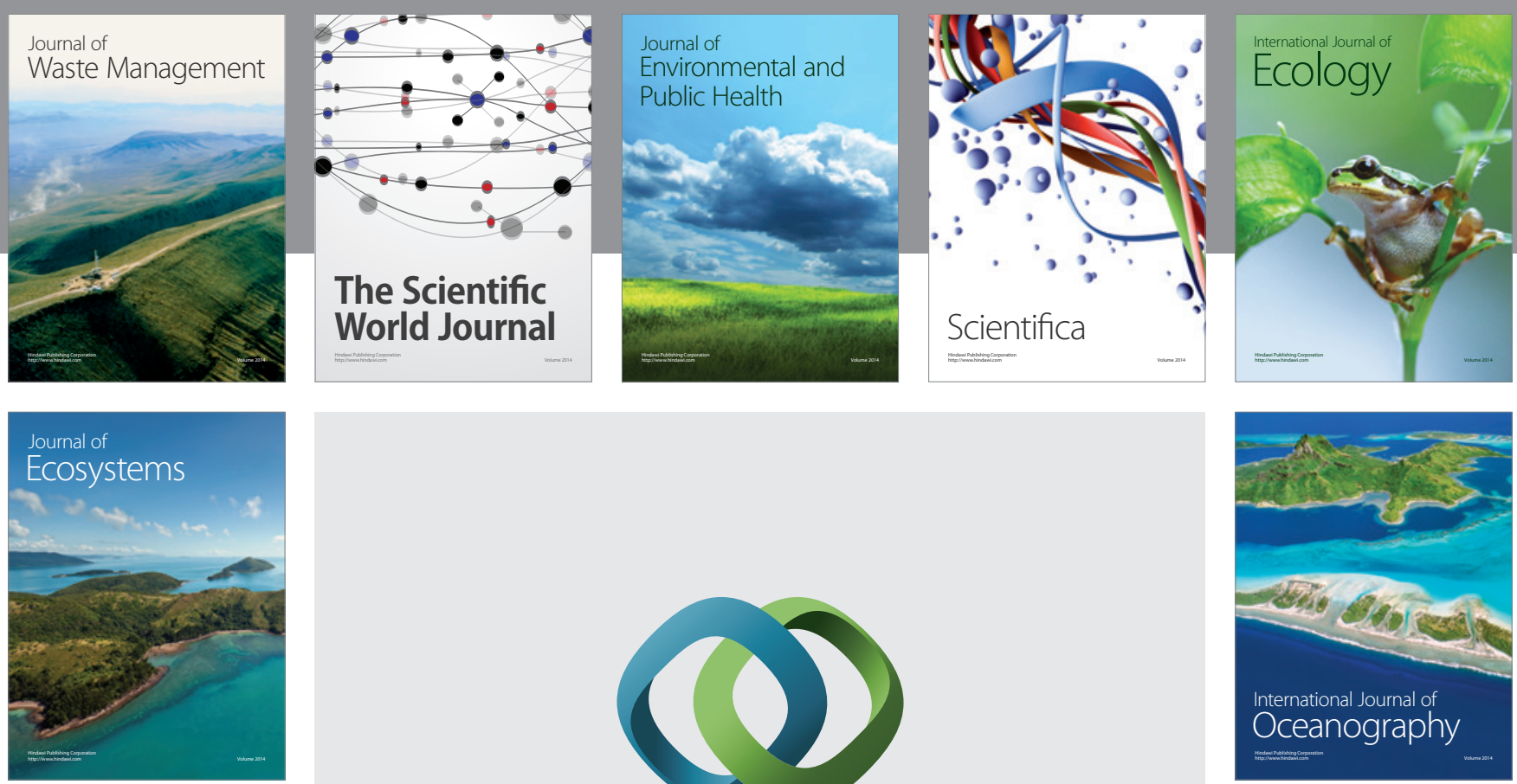

The Scientific World Journal
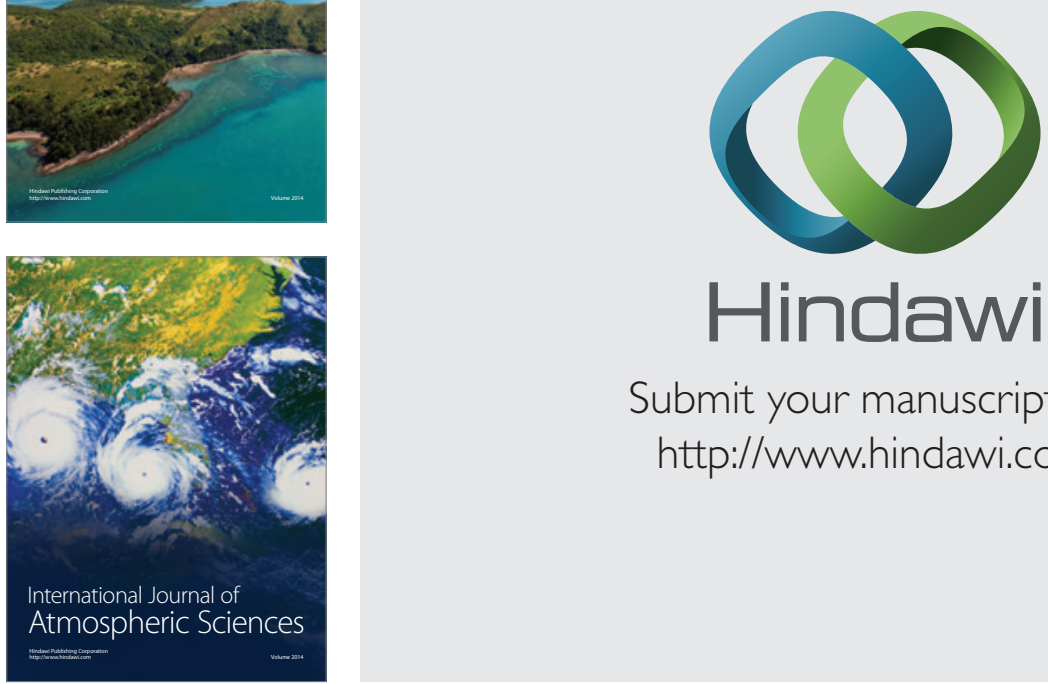

\section{Hindawi}

Submit your manuscripts at

http://www.hindawi.com
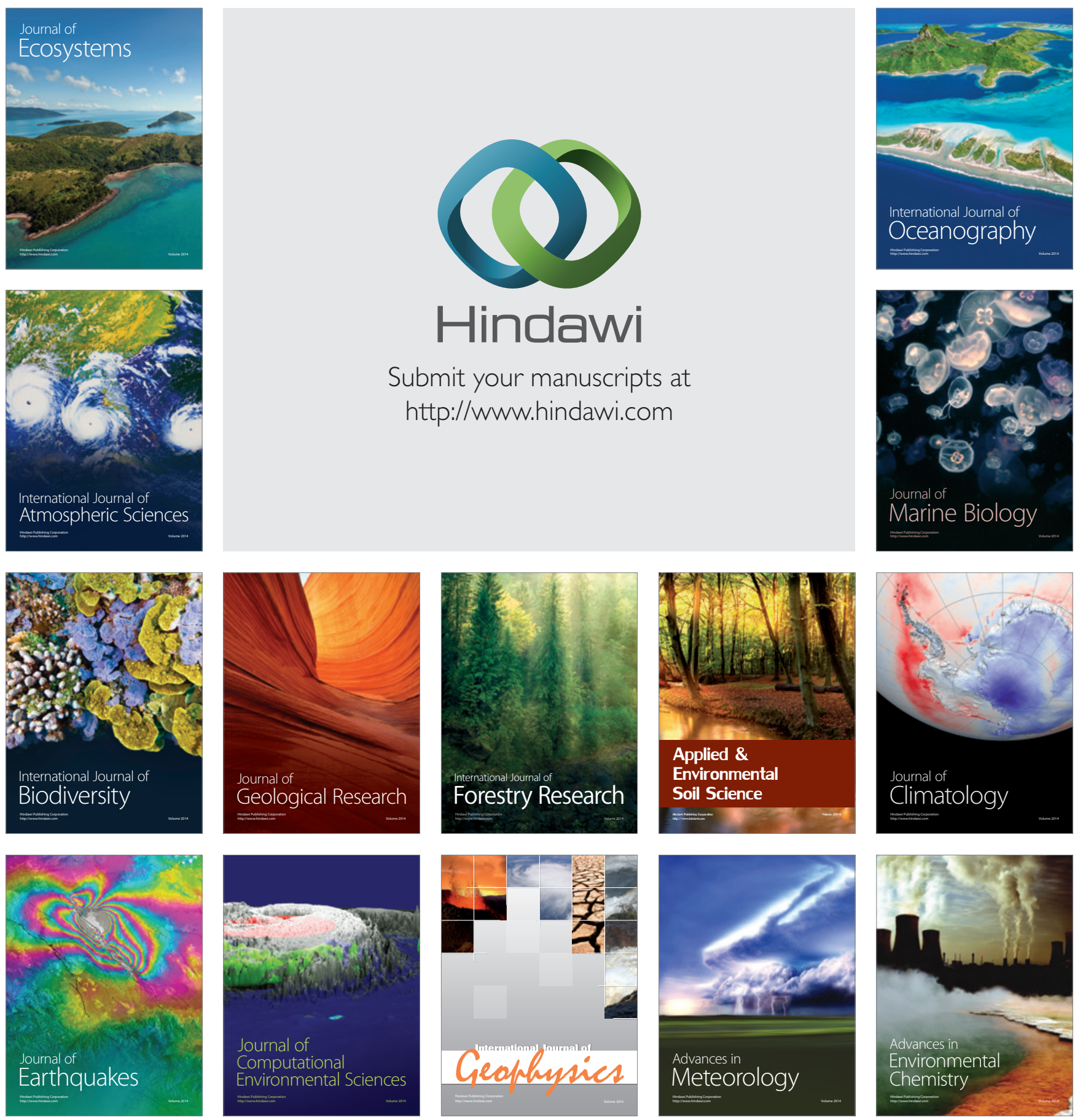